\title{
Prevalence high risk Human Papillomavirus (HPV) in HIV-infected women from Belém, Pará, Amazon region of Brazil: A cross-sectional study
}

Jacqueline Monteiro

Universidade Federal do Para

Ricardo Roberto de Souza Fonseca ( $\square$ ricardosf93@outlook.com )

Universidade Federal do Pará https://orcid.org/0000-0003-0312-0553

\section{Tuane Ferreira}

Universidade Federal do Para

Luana Rodrigues

Universidade Federal do Para

Andreza Silva

Universidade Federal do Para

Maria Eduarda Avelino

Universidade Federal do Para

Cláudia Menezes

Universidade Federal do Para

Samara Gomes

Instituto Evandro Chagas

Rodrigo Silvestre

Instituto Evandro Chagas

Andréa da Silva

Universidade Federal do Para

Ilze Pamplona

reference unit specialized in infectious and parasitic diseases

Antônio Vallinoto

Universidade Federal do Para

Ricardo Ishak

Universidade Federal do Para

Luiz Fernando Machado

Universidade Federal do Para 
Keywords: HPV, HIV, sexually transmitted disease, epidemiology, Amazon region

Posted Date: May 18th, 2020

DOI: https://doi.org/10.21203/rs.3.rs-27466/v1

License: (c) (i) This work is licensed under a Creative Commons Attribution 4.0 International License. Read Full License 


\section{Abstract}

Background: Human papillomavirus (HPV) is the most common sexually transmitted disease in the world. Several studies have shown a higher prevalence of HPV infection in HIV-infected women. The aim of this study was to determine the prevalence and the genotype diversity of HPV infection in HIV-infected women.

Methods: From April 2010 to December 2012 cervical specimens were collected from 169 HIV-infected women who screening for cervical cancer at Reference Unit in Belém. The detection of HPV infection was performed by nested PCR and HPV type was performed using the commercial kit.

Results: The prevalence of HPV infection was $63,3 \%$. Of the 47 genotyped samples, $40,4 \%$ was found positive for high risk-HPV 16 and $12.8 \%$ for high risk-HPV 52. HPV infection was predominant in the group of women with no incidence of cytological abnormalities and more prevalent in women of reproductive age, unmarried, low education level and who used condoms during sexual intercourse. It was observed an association between HPV infection and independent variables, such as condom use, multiple sexual partners and history of sexually transmitted diseases.

Conclusions: High-risk types of HPV infection were prevalent in our study. Infection with multiple high-risk HPV genotypes may potentiate the development of cervical cancer in HIV-infected women.

\section{Background}

Human papillomavirus (HPV) belongs to the Pappillomaviridae family, which is composed of 49 genera and includes papillomaviruses that infect several vertebrate classes. 1 Morphologically, papillomaviruses are non-enveloped viruses, approximately $55 \mathrm{~nm}$ in diameter. The capsid exhibits icosahedral symmetry and surrounds the viral genome, a double-stranded circular DNA molecule of approximately 8000 nucleotide base pairs (bp). Thus far, more than 100 HPV genotypes have been isolated and identified via complete DNA sequencing [1].

HPV infects the epithelial surface and can lead to the development of proliferative benign lesions in the skin, mucosa and genital tract [2]. Genital HPV infection is among the sexually transmitted infections (STIs) with the highest incidence and prevalence worldwide [3-6] and is associated with the development of low- to high-grade squamous intraepithelial lesions (LSIL and HSIL, respectively).

Currently, the World Health Organization pinpoints HPV as the causal agent of cervical cancer, and virus types are classified as high- and low-risk according to their oncogenic potential. The most common lowrisk HPV types are HPV- 6 and HPV-11, which are most frequently detected in benign genital warts $[7,8]$. Among the most prominent high-risk types, HPV-16, HPV-18, HPV-31 and HPV-45 are frequently found in squamous cell carcinomas of the cervix, accounting for almost $80 \%$ of cases [9] HPV-16 and HPV-18 are responsible for $50 \%$ and $20 \%$ of all cases worldwide, respectively [10,11]. 
The prevalence of HPV infection can vary significantly according to the studied population and HPV detection methods. High rates have been described among sexually active adolescent girls and human immunodeficiency virus (HIV)-positive women [12-14]. In immunocompetent women, HPV infection resolves within up to 24 months. However, approximately $10 \%$ of affected women develop a persistent infection [15]. The high rate of HPV prevalence among HIV-infected women is thought to be due to the compromised immune system caused by HIV infection, thus enabling viral persistence of HPV [16] and increasing the probability of contracting infections from multiple HPV genotypes, resulting in a higher risk of progression to cervical neoplasia [17].

The HPV types related with the development of HSIL and cervical intraepithelial neoplasia (CIN) in HIVpositive women are not well characterized. In this sense, the present study aimed to describe the prevalence of infection by different HPV types among HIV-positive women in the city of Belém, Pará State, Brazil.

\section{Materials And Methods}

The present work is an observational population-based cross-sectional prevalence study in which epidemiological information was obtained from a single data collection. Abiding by resolutions 196/96 and 347/05 of the National Health Council, the present project was submitted to review and was approved by the Research Ethics Committee of the Instituto de Ciências da Saúde of the Universidade Federal do Pará - UFPA, under the protocol number 1765/10.

The studied population was composed of women, between 19 and 66 years of age, with a previously confirmed diagnosis of HIV-1 infection under clinical-laboratory follow-up at the Unidade de Referência de Doenças Infecto-Parasitárias Especiais (UREDIPE), a reference center that provides HIV services and care for HIV within the public health system in city of Belém, Pará, Brazil.

Uterine cervix samples were collected from 169 women who sought care spontaneous at the Cervical Cancer Prevention Sector of the UREDIPE-PA during the period of March 2010 to December 2012. Two samples were collected from each participant: one was processed on slides for cytological analysis according to the guidelines for cervical cancer screening of the Ministry of Health of Brazil, and the other was submitted to molecular biological analysis for HPV testing.

Slides were stained by the Papanicolaou method and were analyzed by a professional specializing in cytopathology at the Laboratório Central do Estado do Pará (LACEN-PA). Cytology results were classified according to the Brazilian Nomenclature for Cervical Cytology Reports (Nomenclatura Brasileira para Laudos Citopatológicos Cervicais) [18]. Descriptive diagnosis involves normal cytological limits of the examined material, the occurrence of benign alterations (inflammation, repair, immature squamous metaplasia, inflammatory atrophy, radiation) and the occurrence of pre-malignant or malignant alterations (atypia of undetermined significance - squamous, glandular and of undetermined origin; LSIL; HSIL; carcinoma in situ). 
Uterine cervix samples intended for molecular biological analysis were collected with endocervical brushes and placed in flasks containing $2 \mathrm{~mL}$ of phosphate-buffered saline (PBS). After collection, samples were taken to the Virology Laboratory of the Institute of Biological Sciences of the UFPA, where they were registered and stored at $-20^{\circ} \mathrm{C}$ until use.

All samples were submitted to total DNA extraction from stratified epithelial cells (cervix sample) by means of phenol-chloroform extraction. This method is performed in three stages: red blood cell lysis, white blood cell lysis, and protein precipitation [19].

The HPV L1 open reading frame (ORF) (450 bp) was amplified by means of nested-PCR with the senseprimer pairs MY09/11 (first stage) and GP05+/06+ (second stage), which were previously described for Demathe et al, 201020. Each reaction contained a final volume of $50 \mu \mathrm{L}$ with $200 \mathrm{ng}$ of extracted DNA; $200 \mu \mathrm{M}$ of each dNTP; 10 pmol of each primer; $50 \mathrm{nM} \mathrm{KCL}, 2.5 \mathrm{mM} \mathrm{MgCl}$; $10 \mathrm{mM}$ Tris-HCl, pH 8.3, and 1 $\mathrm{U}$ of Taq polymerase [20].

All amplifications were performed in a Peltier Thermal Cycler (Biocycler, USA) using the following settings: $95^{\circ} \mathrm{C}$ for $5 \mathrm{~min}, 40$ cycles of $\left(95^{\circ} \mathrm{C}\right.$ for $1 \mathrm{~min} ; 56^{\circ} \mathrm{C}$ for $1 \mathrm{~min} ; 72^{\circ} \mathrm{C}$ for $\left.1 \mathrm{~min}\right)$, and a final extension at $72^{\circ} \mathrm{C}$ for $10 \mathrm{~min}$. PCR products were submitted to electrophoresis (100 V/45 min) in $2 \%$ (HPV) and $3 \%$ (interleukin genes) agarose gel with 1x TAE buffer containing $6 \mu \mathrm{L}$ of SYBR Safe (Invitrogen, Oregon, USA) and were then visualized in a UV transilluminator.

HPV genotyping was performed with the Linear Array HPV Genotyping Test (Roche Molecular Systems, Inc., New Jersey, USA) according to the manufacturer's instructions. This method allows the detection of 45 different types of genital HPV.

Information on $\mathrm{CD}^{+} / \mathrm{CD} 8^{+} \mathrm{T}$ lymphocyte counts and plasma HIV-1 viral load was obtained by means of access to the Laboratory Test Control System of the Brazilian National CD4+/CD8- T Lymphocyte Count and Viral Load Network (Sistema de Controle de Exames Laboratoriais da Rede Nacional de Contagem de TCD4+/CD8- e Carga Viral - SISCEL).

The results on HPV prevalence in HIV-1-infected patients were correlated with epidemiological information obtained from interviews using Chi-square test, G-test and Exact Fisher's Test in BioEstat software, version 5.3 [21].

\section{Results}

The global prevalence of HPV infection in the studied population was 63.3\% (107/169). Epidemiological profile analysis of the group of HIV-positive women co-infected with HPV revealed that infection was most prevalent among women of reproductive age $(64.5 \%$; 69/107); between 19 and 38 years; single, separated or widowed $(55.1 \% ; 59 / 107)$; and with a low education level $(52.3 \% ; 56 / 107)$. Furthermore, prevalence decreased with increasing age, with a 1.6 odds ratio of infection in the group of women of reproductive age. 
There were no statistically significant relationships between HPV infection and the variables age, marital status and education level. There were also no statistically significant relationships with the risk factors for infection by HPV (drinking, smoking and illegal drug use), given that the highest prevalence of infection was found in the group that exhibited none of these habits (Table 1).

With respect to sexual behavior, approximately half the HPV-infected women (50.4\%) had their first sexual intercourse at the age of 15 years. Most self-reported to be heterosexual $(96.2 \%$; 103/107), with an active sex life $(76.6 \% ; 72 / 107)$, in a steady relationship $(69.2 \% ; 74 / 107)$ and to practice anal sex $(46.7 \%$; $50 / 107)$. There were statistically significant associations between infection and the use of condoms and with the number of different sex partners in the past year, with a 2.6-fold higher chance of infection in the group of women who regularly used condoms during sexual intercourse (Table 2).

The occurrence of HPV infection was highest in the group of women with a previous history of STIs (68.2\%; 73/107), no history of genital warts $(65.4 \% ; 70 / 107)$, and on antiretroviral therapy (ART). The chance of acquiring an HPV infection was 17.6-fold higher in the group with a history of STIs and 2-fold higher in the group with a history of genital warts (Table 3).

With respect to cytology, two samples were unsuitable for analysis. Only 3.5\% (6/169) of the examined cervical smears were free of cellular alterations. Furthermore, 75.8\% (128/169) exhibited some type of benign alteration, and $19.5 \%$ (33/169) exhibited pre-malignant alterations. There was no statistically significant difference between cytology results and HPV infection (Table 4).

Among women with normal cytology, HPV was present in $83.3 \%(5 / 6)$ of the examined material. In the group of women with cytological alterations, HPV was detected in $60.2 \%(77 / 128)$ of the cases with benign alterations and in $72.7 \%(24 / 33)$ of those with pre-malignant alterations (Table 4).

In the group of women with benign alterations (128/169), inflammatory alterations associated with microorganisms corresponded to 70.3\% (90/128) of the cases, among which HPV was detected in 61 samples (67.8\%). With respect to samples with a nonspecific inflammatory smear $(29.7 \% ; 38 / 128)$, HPV was detected in 16 specimens (42.1\%).

The analysis of the type of benign alteration identified in the studied sample exhibited a statistically significant association with HPV infection, with a 2.9-fold higher odds ratio in the group that exhibited alterations associated with the presence of microorganisms (Table 4).

Among the inflammatory alterations associated with the presence of microorganisms $(n=90), 40 \%$ (36/90) corresponded to microbiological findings (Lactobacillus, cocci and other bacilli). Bacilli suggestive of infections by Gardnerella vaginalis were found in $32.2 \%(29 / 90)$ of the examined women. The presence of Trichomonas vaginalis and findings suggestive of HPV infection were observed in $6 \%$ of the cases.

With respect to pre-malignant alterations, 28 (84.8\%) of the 33 samples exhibited intraepithelial lesions, among which 15 (45.4\%) were HSIL and 13 (39.4\%) were LSIL. The occurrence of atypical squamous 
cells of undetermined significance (ASC-US) was identified in $12.1 \%(6 / 33)$ of the samples. One case of invasive carcinoma $(\mathrm{Ca})$ was also detected. However, there was no statistically significant relationship between the different grades of intraepithelial lesion and the presence of HPV $(G=0.3439 ; p=0.8420$; Table 4).

Genotyping identified the HPV types in as few as $43.9 \%$ (47/107) of the samples. Twenty-six different types were identified, among which the most prevalent were HPV-16 (40.4\%; 19/47), HPV-52 (12.8\%; $6 / 47)$ and HPV-84 $(8.5 \%$; 4/47). Partial genotyping of the sample might be due to divergences in methodology, given that HPV was detected via nested-PCR, whereas genotyping was performed by means of linear array HPV genotyping.

Furthermore, among the genotyped samples, 51.0\% (24/47) exhibited infection by a single genotype, among which HPV-16 was found in 37.5\% (9/24), followed by HPV-61 in $12.5 \%$ (3/24). Infections by multiple genotypes corresponded to 49\% (23/47), among which HPV-16 and HPV-52 were detected in $43.5 \%(10 / 23)$ and $21.7 \%(5 / 23)$ of cases, respectively (Table 5).

The classification of species according to oncogenic potential showed that $72.3 \%$ (34/47) of the infections were high-, $21.3 \%$ low-, and $6.4 \%$ intermediate-risk genotypes. Among the samples with infections by multiple genotypes, 39.1\% (9/23) exhibited more than one high-risk genotype (Table 5). There were no statistically significant differences between levels of $C D 4^{+}$or $C D 8^{+} T$ lymphocytes, plasma HIV viral load and HPV infection.

\section{Discussion}

In Brazil, according to data of the National Cancer Institute (Instituto Nacional de Câncer - INCA) (2015), cervical cancer is the most common cancer type among women of the North Region of the country, with an estimated risk of 23,97 cases per 100 thousand women. Many studies have shown that an infection by an HPV of high oncogenic risk, especially HPV-16 and 18, is closely related with the development of cervical cancer, with a higher chance of occurrence among HIV-positive women [9].

According to studies in the literature, HPV infection occurs in the first two consecutive years after first sexual intercourse, given that the incidence is higher among women below 25 years of age $[13,22]$. In the present study, among the group of HPV-infected women, the mean age was of 36 years, and infection was predominant among women of reproductive age, with a trend to reduced prevalence with increasing age. Similar data have been described in other Brazilian cities [23-25]. The results of the present study suggest that the reduced prevalence of infection in the group of women aged 39 years and above is due to marriage and, thus, reductions in both the number of partners and exposure to HPV.

Several epidemiological and reproductive health factors have been related with the development of cervical cancer, including HPV, smoking, genetic predisposition, number of sex partners, age of first sexual intercourse, parity, miscarriages and age at menarche [26] With respect to HPV infection, with the 
exception of immunosuppression caused by HIV, the literature is controversial with regard to establishing the risk factors for the acquisition of infection.

Studies on the general population of the North Region of Brazil have found diverging epidemiological associations between the examined population groups. In the Brazilian Eastern Amazon, there were strong associations between HPV infection and marital status, the use of condoms and the number of sex partners throughout life and in the past year [27]. The association between HPV infection and age range has been described in women of the general population, in female inmates in the Metropolitan Region of Belém [28] and in women in the municipality of Tomé-Açu [29].

Based on the results of the present study, even the regular use of condoms does not seem to provide total protection against microbial infection, given that the condom does not fully cover the male reproductive organ, hence leaving areas potentially harboring infectious particles or subclinical lesions, in the case of HPV, exposed during sexual intercourse. A history of multiple sex partners is an important risk factor for the acquisition of HPV because the higher the number of partners, the higher the odds of acquiring an infection by HPV and other STIs.

The innate immune system is known to have many protection mechanisms in the vaginal tissue against infections by pathogens, in part by ensuring the survival of the normal vaginal microbiota, which constitutes an important factor in the production of lactic acid and hydrogen peroxide, thus inhibiting pathogen growth. The acquisition of STIs promotes an imbalance in the vaginal microbiota, altering the $\mathrm{pH}$ and also possibly causing lesions in the lining epithelium of the cervix and vaginal wall. These changes might contribute to the development of inflammation and pathogen penetration, including HPV. In addition to the observed association between a previous history of STIs and HPV infection, the present study found that many women exhibited clinical features compatible with bacterial vaginosis, candidiasis and trichomoniasis, suggesting that the establishment of these infections might contribute to the acquisition and onset of HPV infection. Similar data have been reported by Grinsztejn et al [25] in Rio de Janeiro, whereas Gonçalves et al [30] found that age was the only variable associated with HPV infection in anogenital samples from HIV-positive women.

The global prevalence of HPV infection among HIV-1-positive women in the present study corroborates the findings of Gonçalves et al [30] but is lower than the rates observed in other Brazilian regions [24,31]. Among immunocompetent women of the North Region, the prevalence rate of HPV infection varies between $6 \%, 9 \%$ and $18 \%[27,29,32]$ showing that the incidence of HPV infection is high in the population of HIV-positive women.

The majority of HPV infections are clinically unapparent or asymptomatic in immunocompetent individuals [33,34]. However, the immunosuppression caused by HIV seems to favor infection by multiple HPV genotypes, which, if oncogenic, might contribute to the progression of intraepithelial lesions to CIN. According to Luque et al [35] the presence of multiple HPV genotypes in HIV-positive women is a poor indicator of prognosis in cases of CIN. In the present study, $49 \%$ (23/47) of the studied population 
exhibited infections by multiple genotypes, and, of these, $39.1 \%$ exhibited more than one high-risk genotype.

Previous studies have shown that the prevalence rates of lesions and CIN are higher among HIV-positive women compared to women from the general population $[12,14,31,36,37]$ HIV infection is thought to change the natural history of HPV infection, favoring higher HPV persistence, reduced lesion regression rates and, consequently, progression to high-grade or invasive squamous intraepithelial lesions [38,39].

Some studies suggest that the persistence of HPV is inversely proportional to CD $4^{+} \mathrm{T}$ lymphocyte count and directly proportional to HIV viral load, which can also be influenced by ART [39-41]. However, there was no association between markers of HIV infection and HPV infection or between the different grades of intraepithelial lesions in the present study. These data corroborate other studies on HIV-positive women from the Southeast Region of Brazil $[23,25]$. Thus, it is suggested that ART is efficient in the maintenance of low levels of HIV replication, avoiding the abrupt depletion of CD4 ${ }^{+} \mathrm{T}$ lymphocyte levels. However, the effect of ART on the persistence of HPV infection has not yet been characterized in the literature due to the absence of studies on that topic.

\section{Conclusions}

The data obtained in the present study show the high prevalence of HPV infection among HIV-positive women and reinforce the notion that immunocompromised women tend to develop infections by multiple high-risk HPV genotypes. Thus, the importance of molecular diagnosis of HPV infection associated with oncotic cytology in the early detection of cases, with the aim of avoiding progression to $\mathrm{CIN}$, is reinforced.

\section{List Of Abbreviations}

HPV: Human papillomavirus; HIV: Human immunodeficiency virus; STIs: Sexually transmitted infections; HSIL: High-grade squamous intraepithelial lesions; LSIL: Low-grade squamous intraepithelial lesions; CIN: Cervical Intraepithelial Neoplasia; UFPA: Universidade Federal do Pará; UREDIPE: Unidade de Referência de Doenças Infecto-Parasitárias Especiais; LACEN: Laboratório Central; INCA: Instituto Nacional do Câncer

\section{Declarations}

\section{Ethics approval and consent to participate}

This research has been approved by the Research Ethics Committee of the Instituto de Ciências da Saúde of the Universidade Federal do Pará - UFPA, under the protocol number 1765/10.

\section{Consent for publication}

Not applicable. 
All data generated or analyzed during this study are included in this published article. The raw data belongs to the Virus Laboratory of the Federal University of Para. The data cannot be accessed without the approval of the Ethical Committee of Federal University of Para, as there are ethical restrictions on the data, given that the research deals with information starting from biological samples taken from patients. Interested researchers should send requests to access the data to the corresponding author.

\section{Competing interests}

The authors declare that they have no competing interests.

\section{Funding}

This study was funded by Coordenação de Aperfeiçoamento de Pessoal de Nível Superior (CAPES), Ministry of education - Brazil- Grant code 001. The publication of this article was supported by Public Notice PAPQ, PROPESP/FADESP of the Federal University of Pará.

\section{Author Contributions}

Conception and design of the study: LFAM, RI, ACRV, and JCM. Analysis and interpretation of the data: JCM and LFAM. Collection and assembly of the data: JCM, STMG, TCSF, RVDS, RI, RRSF, MESA, CRM, ACRV and LFAM. Drafting of the article: JCM, RRSF, RI, LFAM and ACRV. Critical revision of the article for important intellectual content: JCM, STMG, TCSF, RVDS, ANMRS, RI, ACRV and LFAM. Final approval of the article: ACRV, RI and LFAM. All authors read and approved the final manuscript.

\section{Acknowledgments}

We acknowledge all subjects enrolled in the present study. We thank the Secretaria Estadual de Saúde (SESPA) and UREDIPE.

\section{References}

1. ICTV. Virus Taxonomy: 2017 Release. Available online: http://www.ictvonline.org/virusTaxonomy.asp. (accessed on 12 August 2018).

2. Finnen RL, Erickson KD, Chen XS, Garcea RL. Interactions between papillomavirus L1 and L2 capsid proteins. J Virol. 2003;77:4818-26.

3. Wright Jr TC. Natural history of HPV infections. J Fam Pract. 2009;58:S3.

4. Shavit O, Raz R, Stein M, Chodick G, Schejter E, Ben-David Y, et al. Evaluating the epidemiology and morbidity burden associated with human papillomavirus in Israel: accounting for CIN1 and genital warts in addition to CIN2/3 and cervical cancer. Appl Health Econ Health Policy. 2012; 10(2):87-97. 
5. Caterina Cortés-Alaguero, Esteban González-Mirasol, José Morales-Roselló, Enrique Poblet-Martinez. Do clinical data and human papilloma virus genotype influence spontaneous regression in grade I cervical intraepithelial neoplasia? J Turk Ger Gynecol Assoc 2017; 18: 1-8.

6. Aleksandra Paluszkiewicz, Dominik Pruski, Kinga Iwaniec, Witold Kędzia. Comparison of the diagnostic value of cervical cytology and HPV HR DNA testing for the diagnosis of low-grade and high-grade squamous intraepithelial lesions across different age groups. Ginekologia Polska 2017; 88, 3: 141-146

7. Dunne EF, Markowitz LE. Emerging infections: genital human papillomavirus infection. Clin Infect Dis. 2006;43:624-9.

8. Garnett TO, Duerksen-Hughes PJ. Modulation of apoptosis by human papillomavirus (HPV) oncoproteins. Arch Virol. 2006;151:2321-35.

9. Bosch FX, Sanjosé SD. Human papillomavirus in cervical cancer. Curr Oncol Rep. 2002;4:175-84.

10. Dueñas-González A, Lizano M, Candelaria M, Cetina L, Arce C, Cervera E. Epigenetics of cervical cancer. Na overview and therapeutic perspectives. Mol Cancer. 2005;4:38.

11. Schiffman M, Cliffford G, Buonaguro FM. Classification of weakly carcinogenic human papillomavirus types: Addressing the limits of epidemiology at the borderline. Infect Agent Cancer. 2009;4:8.

12. Minkoff H, Feldman J, DeHovitz J, Landesman S, Burk R. A longitudinal study of human papillomavirus carriage in human immunodeficiency virus-infected and human immunodeficiency virus-uninfected women. Am J Obstet Gynecol. 1998;178:982-6.

13. Moscicki A-B. HPV Infections in adolescents. Dis Markers. 2007;23:229-34.

14. Ng'andwe C, Lowe JJ, Richards PJ, Hause L, Wood C, Angeletti PC. The distribution of sexuallytransmitted human papillomaviruses in HIV positive and negative patients in Zambia, Africa. BMC Infect Dis. 2007;7:77.

15. Wentzensen N, Schiffman M, Dunn ST, et al. Grading the severity of cervical neoplasia based on combined histopathology, cytopathology, and HPV genotype distribution among 1,700 women referred to colposcopy in Oklahoma. Int J Cancer. 2009;124:964-9.

16. Strickler HD, Palefsky JM, Shah KV, et al. Human papillomavirus type 16 and immune status in human immunodeficiency virus-seropositive women. J Natl Cancer Inst. 2003;95:1062-71.

17. Mbulawa ZZA, Marais DJ, Johnson LF, Coetzee D, Williamson AL. Impact of human immunodeficiency virus on the natural history of human papillomavirus genital infection in South African men and women. J Infect Dis. 2012;206:15-27.

18. BRASIL. Ministério da Saúde. Secretaria de Atenção à Saúde. Instituto Nacional do Câncer. Nomenclatura brasileira para laudos cervicais e condutas preconizadas: recomendações para profissionais de saúde. Rio de Janeiro, INCA, 65p. 2006.

19. Sambrook J, Fritsch EF, Maniatis T. Molecular cloning: a laboratory manual. New York: Cold Spring Harbor Laboratory Press, 1989. 
20. Demathe A, Bernabé DG, Garcia JF, Nunes CM, Miyahara GI. Comparação entre dois métodos de detecção de DNA de papilomavírus humano em carcinoma epidermoide de lábio. J Bras Patol Med Lab. 2010;46:85-90.

21. Ayres M, Ayres JRJ, Ayres DL, Santos AS. BioEstat 5.3. Aplicações Estatísticas nas áreas das ciências biológicas e médicas. Sociedade Civil de Mamirauá, Belém. 2011.

22. Rama CH, Roteli-Martins CM, Derchain SFM, et al. Prevalência do HPV em mulheres rastreadas para o câncer cervical. Rev Saude Publica. 2008;42:123-30.

23. Corrêa CM, Teixeira NC, de Araújo ACL, et al. Prevalence and multiplicity of HPV in HIV women in Minas Gerais, Brazil. Rev Assoc Med Bras. 2011;57:425-30.

24. Entiauspe LG, Teixeira LO, Mendoza-Sassi RA, Gonçalves CV, Gonçalves P, Martinez AMBD. Papilomavírus humano: prevalência e genótipos encontrados em mulheres HIV positivas e negativas, em um centro de referência no extremo Sul do Brasil. Rev Soc Bras Med Trop. 2010;43:260-3.

25. Grinsztejn B, Veloso VG, Levi JE, et al. Factors associated with increased prevalence of human papillomavirus infection in a cohort of HIV-infected Brazilian women. Int J Infect Dis. 2009;13:72-80.

26. BRASIL. Boletim Epidemiológico AIDS-DST (versão preliminar). Ministério da Saúde. Secretaria de Vigilância em Saúde - Departamento de DST, Aids e Hepatites Virais, Brasília, DF.p3-26, 2012.

27. Pinto DDS, Fuzii HT, Quaresma JAS. Prevalência de infecção genital pelo HPV em populações urbana e rural da Amazônia Oriental Brasileira. Cadernos de Saúde Pública. 2011;27:769-78.

28. Plácido WS. Epidemiologia da infecção genital pelo Papilomavírus humano (HPV) em população feminina geral e carcerária. Dissertação (Mestrado em Doenças Tropicais), 76p, 2012.

29. Prazeres BAP. Prevalência de HPV em material cérvico-uterino de mulheres de Tomé-Açu, Pará. Dissertação (Mestrado em Doenças Tropicais), 56p, 2011.

30. Gonçalves M, Randi G, Arslan A, et al. HPV type infection in different anogenital sites among HIVpositive Brazilian women. Infect Agent Cancer. 2008;3:1-7.

31. Levi J, Fernandes S, Tateno AF, et al. Presence of multiple human papillomavirus types in cervical samples from HIV-infected women. Gynecol Oncol. 2004;92:225-31.

32. Noronha V, Cruz EM, Pinho CN, Mello WA, Villa LL, Russomano FB. PaPilomavírus Humano (HPv) em mulHeres submetidas a rastreamento Para CânCer de CérviCe uterina, Belém - Pará - Brasil. Jornal Brasileiro de Doenças Sexualmente Transmissíveis. 2011;23:5-11.

33. Oliveira-Silva M, Lordello CX, Zardo LMG, Bonvicino CR, Moreira MAM. Human papillomavirus in Brazilian women with and without cervical lesions. Virol J. 2011;8:1-6.

34. Rocha DAP, Barbosa Filho RAA, de Queiroz FA, dos Santos CMB. High Prevalence and genotypic diversity of the human papillomavirus in Amazonian women, Brazil. Infect Dis Obstet Gynecol. 2013;2013:1-6.

35. Luque E, Jabeen M, Messing S, et al. Prevalence of human papillomavirus Genotypes and related abnormalities of cervical cytological results among HIV-1-infected women in Rochester, New York. J 
Infect Dis. 2006;194:428-34.

36. Smits PHM, Bakker R, Jong E, et al. High prevalence of human papillomavirus infections in urine samples from human immunodeficiency virus-infected men. J Clin Microbiol. 2005;43:5936-9.

37. Levi JE, Klete B, Quint, WGV, Fink, MCS, Canto, CLM, Matsubara R., Linhares I, Segurado S, Vanderborght B, Neto JE, Van Doorn LJ. High prevalence of Human papillomavirus (HPV) infections and high frequency of multiple HPV genotypes in Human immunodeficiency virus-infected women in Brazil. J Clin Microbiol, 40(9): 3341-3345, 2002.

38. Joshi SN, Gopalkrishna V, Kumar BK, et al. Cervical squamous intra-epithelial changes and human papillomavirus infection in women infected with human immunodeficiency virus in Pune, India. J Med Virol. 2005;76:470-5.

39. Palefsky J. Biology of HPV in HIV Infection. Adv Dent Res. 2006;19:99-105.

40. Jalil EM, Duarte G, El Beitune P, Simões RT, Melli PPDS, Quintana SM. High prevalence of human papillomavirus infection among Brazilian pregnant women with and without human immunodeficiency virus type 1. Obstet Gynecol Int. 2009;2009:1-4.

41. Ogoina D, Musa BO, Onyemelukwe GC. Human papilloma virus (HPV) infection is associated with HIV-1 infection and AIDS in HIV-infected adult patients from Zaria, Northern Nigeria. Pan Afr Med J. 2013;15:1-3.

\section{Tables}

Table 1. Demographic characteristics of women co-infected with HPV/HIV who were seen at the UREDIPE in the period between April 2010 and December 2012. 
Demographic variables

\begin{tabular}{|c|c|c|c|c|c|c|}
\hline & $\mathbf{N}$ & $\%$ & $\mathbf{N}$ & $\%$ & & \\
\hline Age & & & & & 1.6 & 0.2465 \\
\hline $19-28$ years & 26 & 24.3 & 08 & 12.9 & & \\
\hline 29-38 years & 43 & 40.2 & 28 & 45.2 & & \\
\hline $39-48$ years & 23 & 21.5 & 18 & 29.0 & & \\
\hline $49-58$ years & 05 & 4.7 & 07 & 11.3 & & \\
\hline > 59 years & 04 & 3.7 & 01 & 1.6 & & \\
\hline Not informed * & 06 & 5.6 & - & & & \\
\hline Total & 107 & 100 & 62 & 100 & & \\
\hline Marital status & & & & & 1.3 & 0.2692 \\
\hline Single/separated/widowed & 59 & 55.1 & 31 & 50.0 & & \\
\hline Married/stable union & 46 & 43.0 & 31 & 50.0 & & \\
\hline Not informed * & 02 & 1.9 & - & & & \\
\hline Total & 107 & 100 & 62 & 100 & & \\
\hline Education level & & & & & 1.3 & 0.4240 \\
\hline$\leq 8$ years & 56 & 52.3 & 28 & 45.2 & & \\
\hline$>8$ years & 50 & 46.7 & 34 & 54.8 & & \\
\hline Not informed * & 01 & 1.0 & - & - & & \\
\hline Total & 107 & 100 & 62 & 100 & & \\
\hline Drinking & & & & & 0.7 & 0.2953 \\
\hline Yes & 41 & 38.3 & 29 & 46.8 & & \\
\hline No & 65 & 60.7 & 31 & 50.0 & & \\
\hline Not informed * & 01 & 1.0 & 02 & 3.2 & & \\
\hline Total & 107 & 100 & 62 & 100 & & \\
\hline \multicolumn{7}{|l|}{ Smoking } \\
\hline Yes & 24 & 22.4 & 12 & 19.4 & 1.2 & 0.7996 \\
\hline No & 82 & 76.6 & 49 & 79.0 & & \\
\hline Not informed * & 01 & 1.0 & 01 & 1.6 & & \\
\hline
\end{tabular}




\begin{tabular}{lcccccc} 
Total & 107 & 100 & 62 & 100 & & \\
\hline Illegal drugs & & & & & 1.8 & 0.4911 \\
\hline Yes & 11 & 10.3 & 04 & 6.5 & & \\
\hline No & 86 & 80.4 & 56 & 90.3 & & \\
\hline Not informed * & 10 & 9.3 & 02 & 3.2 & & \\
\hline Total & 107 & 100 & 62 & 100 & &
\end{tabular}

* Not included in statistical analysis. $\left({ }^{1}\right)$ Odds ratio.

Table 2. Distribution of sexual behavior variables in a group of women co-infected with HPV/HIV who were seen at the UREDIPE and who had Pap smears in the period between April 2010 and December 2012. 
Variables

HIV+/HPV (+) $\quad$ HIV+/HPV (-) $\quad$ OR $^{1} \quad P$ value

\begin{tabular}{|c|c|c|c|c|c|c|}
\hline & $\mathrm{N}$ & $\%$ & $\mathrm{~N}$ & $\%$ & & \\
\hline Age of first sexual intercourse & & & & & 1.2 & 0.5961 \\
\hline$\leq 15$ years & 52 & 48.6 & 27 & 43.5 & & \\
\hline$>15$ years & 54 & 50.4 & 35 & 56.5 & & \\
\hline Not informed * & 01 & 1.0 & - & - & & \\
\hline Total & 107 & 100 & 62 & 100 & & \\
\hline \multicolumn{7}{|l|}{ Sexual orientation } \\
\hline Heterosexual & 103 & 96.2 & 61 & 98.4 & 0.6 & 0.9801 \\
\hline Homosexual & 01 & 1.0 & 01 & 1.6 & & \\
\hline Bisexual & 02 & 1.8 & - & - & & \\
\hline Not informed * & 01 & 1.0 & - & - & & \\
\hline Total & 107 & 100 & 62 & 100 & & \\
\hline \multicolumn{7}{|l|}{ Sexually active } \\
\hline Yes & 82 & 76.6 & 43 & 69.4 & 1.5 & 0.3351 \\
\hline No & 24 & 22.4 & 19 & 30.6 & & \\
\hline Not informed * & 01 & 1.0 & - & - & & \\
\hline Total & 107 & 100 & 62 & 100 & & \\
\hline \multicolumn{7}{|l|}{ Steady relationship } \\
\hline Yes & 74 & 69.2 & 39 & 62.9 & 1.4 & 0.3788 \\
\hline No & 26 & 24.3 & 20 & 32.3 & & \\
\hline Not informed * & 07 & 6.5 & 03 & 4.8 & & \\
\hline Total & 107 & 100 & 62 & 100 & & \\
\hline \multicolumn{7}{|l|}{ Use of condom } \\
\hline Regular use & 55 & 51.4 & 19 & 30.6 & 2.6 & 0.0079 \\
\hline Irregular use/does not use & 43 & 40.2 & 39 & 62.9 & & \\
\hline Not informed * & 09 & 8.4 & 04 & 6.5 & & \\
\hline Total & 107 & 100 & 62 & 100 & & \\
\hline
\end{tabular}




\begin{tabular}{lllllll} 
Yes & 50 & 46.7 & 25 & 40.3 & 0.7 & 0.4827 \\
\hline No & 43 & 40.2 & 29 & 46.8 & & \\
\hline Not informed * & 14 & 13.1 & 08 & 12.9 & & \\
\hline Total & 107 & 100 & 62 & 100 & & \\
\hline Partners n\%/past year & & & & & 0.2 & 0.0005 \\
\hline 1 & 47 & 55.2 & 33 & 92.1 & & \\
\hline$>2$ & 40 & 44.8 & 05 & 7.9 & & \\
\hline Total & 87 & 100 & 38 & 100 & &
\end{tabular}

* Not included in the statistical analysis. $\left({ }^{1}\right)$ Odds ratio.

Table 3. Distribution of the variables history of STI and genital warts in a group of women co-infected with HPV/HIV who were seen at the UREDIPE and who had Pap smears in the period of April 2010 to December 2012.

\begin{tabular}{lcccccc} 
Variables & \multicolumn{2}{c}{ HIV+/HPV (+) } & \multicolumn{2}{c}{ HIV+/HPV $(-)$} & OR $^{1}$ & P value \\
\cline { 2 - 5 } & $\mathrm{N}$ & $\%$ & $\mathrm{~N}$ & $\%$ & & \\
\cline { 1 - 5 } History of STI & 73 & 68.2 & 07 & 11.3 & 17.6 & $<0.0001$ \\
\hline Yes & 32 & 29.9 & 54 & 87.1 & & \\
\hline No & 02 & 1.9 & 01 & 1.6 & & \\
\hline Not informed * & 107 & 100 & 62 & 100 & & \\
\hline Total & & & & & 2.0 & 0.2174 \\
\hline History of genital warts & & & & & & \\
\hline Yes & 23 & 21.5 & 07 & 11.3 & & \\
\hline No & 70 & 65.4 & 42 & 67.7 & & \\
\hline Not informed * & 14 & 13.1 & 13 & 21.0 & & \\
\hline Total & 107 & 100 & 62 & 100 & &
\end{tabular}

* Not included in statistical analysis. $\left({ }^{1}\right)$ Odds ratio. 
Table 4. Prevalence of HPV infection with respect to the cytology report in a group of HIV-infected women who were seen at the UREDIPE and who had Pap smears in the period of April 2010 to December 2012.

\begin{tabular}{lllll} 
Cytology & Overall (\%) & HPV (+) & HPV (-) & Pvalue \\
\hline Normal & $06(3.5 \%)$ & $05(83.3 \%)$ & $01(16.7 \%)$ & $0.2382^{1}$ \\
\hline Benign alterations & $128(75.8 \%)$ & $77(60.2 \%)$ & $51(39.8 \%)$ & \\
\hline Inflammatory + & $90(70.3 \%)$ & $61(67.8 \%)$ & $29(32.2 \%)$ & $0.0099^{2}$ \\
microorganisms & & & & \\
\hline Nonspecific inflammatory & $38(29.7 \%)$ & $16(42.1 \%)$ & $22(57.9 \%)$ & \\
\hline Pre-malignant alterations & $33(19.5 \%)$ & $24(72.7 \%)$ & $09(27.3 \%)$ & \\
\hline ASC-US & $04(12.1 \%)$ & $03(75.0 \%)$ & $01(25.0 \%)$ & $0.8420^{1}$ \\
\hline LSIL & $13(39.4 \%)$ & $10(76.9 \%)$ & $03(23.1 \%)$ & \\
\hline HSIL & $15(45.5 \%)$ & $10(66.7 \%)$ & $05(33.35)$ & \\
\hline CA & $01(3.0 \%)$ & $01(100 \%)$ & - & \\
\hline Unsuitable for analysis * & $02(1.2 \%)$ & $01(50.0 \%)$ & $01(50.0 \%)$ & \\
\hline Total & 169 & 107 & 62 &
\end{tabular}

* Not included in statistical analysis. ${ }^{1}$ G-Test. ${ }^{2}$ Fisher's exact test.

Table 5. Distribution of HPV genotypes identified in a group of women infected with multiple genotypes and co-infected with HIV who were seen at the UREDIPE in the period of April 2010 to December 2012. 


\begin{tabular}{llll} 
Sample & Genotype & Sample & Genotype \\
\hline 22417 & HPV-16* and 61 & 23292 & HPV-52*, 53, 61 and 70 \\
\hline 22435 & HPV-6, 72 and 81 & 23293 & HPV-16*, 52*, 62 and 83 \\
\hline 22444 & HPV-72, 81 and CP6108 & 23307 & HPV-16* and 45* \\
\hline 22447 & HPV-16* and 52* & 23325 & HPV-83 and 69 \\
\hline 22456 & HPV-16*, 52* and 61 & $\mathbf{2 3 3 4 5}$ & HPV-16* and 72 \\
\hline 22485 & HPV-16*, 35* and 52 & 23455 & HPV-54 and 71 \\
\hline 22517 & HPV-16*, 58*, CP6108 & 23459 & HPV-31* and 81 \\
\hline 22520 & HPV-51*, 66 and 83 & 23541 & HPV-18*, 81 and 84 \\
\hline 22526 & HPV-58*, 83 and CP6108 & 23545 & HPV-16*, 73* and 84 \\
\hline 22527 & HPV-52*, 62 and 83 & 23547 & HPV-59* and 62 \\
\hline 22556 & HPV-45* and 70 & 23574 & HPV-18* and 51* \\
\hline 22557 & HPV-16*, 59* and 61 & & \\
\hline
\end{tabular}

* High-risk genotype. 